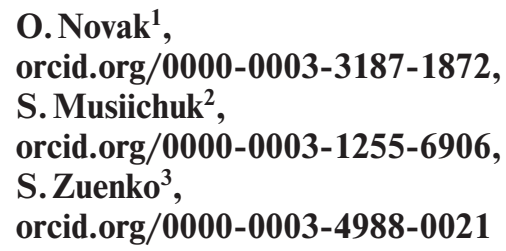

1 - Hryhorii Skovoroda University in Pereiaslav, Pereiaslav, Ukraine, e-mail: novakolyia@gmail.com

2 - National University of Food Technologies, Kyiv, Ukraine 3 - National University of Life and Environmental Sciences of Ukraine, Kyiv, Ukraine

\title{
MANAGEMENT CULTURE: THE ROLE OF UNIVERSITY STARTUPS
}

Purpose. To study the peculiarities of the implementation of a new management culture in higher education in Ukraine.

Methodology. The authors used the methods of analysis and synthesis. Both methods provided the results of reviewing the research literature on the selected issue. Comparison and analogy methods allowed the authors to compare the results of investigating different states and regions, as well as to argue the conclusions.

Findings. The authors found that the formation of a new management culture in higher education was initiated in the United States at the beginning of the 21st century. Two key recommendations from Congress on education policy have opened up a new source of income for universities. Universities were involved in the economic development strategy of the state. They turned from educational institutions into generators of a new management culture, which transformed the intellectual potential of young people into economic growth of the state and resulted in an increase in the well-being of society. The work discusses the peculiarities of the implementation of a new management culture in higher education in Ukraine. Three problems were identified and investigated that make it impossible to fully implement a new management culture in Ukrainian universities at this stage of state development.

Originality. The authors revealed new trends in the formation of management culture in higher education in the United States, and also explored the features of their influence on the reform in higher education in Ukraine.

Practical value. The results of the study should be considered as recommendations for the implementation of the new management culture in higher education in Ukraine. The new management culture pioneered by the U.S. Congress fosters the "innovative spirit" of youth. It transforms the intellectual potential of young people into state capital. The introduction of a new culture of management in higher education in Ukraine will ensure the economic growth of the state and, accordingly, increase the well-being of the Ukrainian society.

Keywords: management culture, university startups, US higher education, university graduates, higher education in Ukraine, higher education reforms

Introduction. The modern universities are under increasing political pressure. Each new change in the system of higher education provides for the involvement of universities in the process of increasing national welfare. Governments allocate money for higher education, but in return they require universities to directly influence the economic growth of the state, create new jobs, increase competitiveness, and influence public health and safety [1].

The Platonic tradition, providing for the joint ascent of teacher and student to knowledge in order to gain wisdom, faded with time [2]. Market relations have been established between governments and universities. The state allocates significant financial resources to universities only under certain return guarantees.

In educational policy, the emphasis was placed on transforming the intellectual potential of young people into the economic growth of the state. The formation of a special "university culture" or "university spirit" was replaced by the formation of a new management culture, which emphasized the development of an "innovative spirit" among students.

Market relations have turned universities from educational institutions into a kind of startup. Universities have evolved into public or private business models specializing in the development and transfer of educational, research and manufacturing technologies. In English-language literature, the phrase "tertiary" education is regularly used in relation to higher education instead of the phrase "higher education" [3].

Drew Gilpin Faust, the President of Harvard University (2007-2018), in an interview with The New York Times, highlighted four key changes that have occurred in American higher education over the past two decades [4]:

1. Universities have lost the status of academic and spiritual centers.

2. Universities have become dependent on Big Business, Big Government and Big Foundations.
3. The redefinition of "professor" to "grant-grubbing entrepreneur".

4. The redefinition of "liberal education" to "a smattering of units in random disciplines rather than a vocational major".

Ukraine is reforming its higher education system using the U.S. and European Union higher education standards. It is based on the Modern Open "Education for Everyone" System, which provides for training students with different educational needs [5]. Therefore, the changes that have taken place and are taking place in the culture of higher education management in the aforementioned states determine the reforms of higher education in Ukraine, as well as the Ukrainian management culture in general.

The purpose of the article is to study the features of the implementation of a new management culture in higher education in Ukraine.

Results. The process of global reforms in the management culture of the U.S. higher education was initiated three decades ago. We consider management culture as an integral element of organizational culture. Management culture ensures high quality functionality of the processes in the organization and allows for changes in the organizational culture and competitive space. "The management culture is something that often develops from the inception of any organization and penetrates into the spirit of the company" [6].

A management culture is not identical to an organizational culture as it encompasses certain parts of the formal and informal organizational culture. P. Žukauskas, et al. distinguish managerial, educational, informational, communication, standardization, regulatory and other functions of the management culture and the categories that make up this phenomenon of an organization [6].

Therefore, when referring to management culture, the study is focused on examining the formation of new, individual and unique characteristics of an emerging organization, 
which will subsequently determine the organizational culture of this, and possibly other organizations.

The formation of a new management culture of higher education in the United States was initiated by two appeals from the U.S. Congress to the National Academies. The appeals resulted from the studies on the effectiveness of the higher education influence on the preparation of university graduates for employment, finding a place in the labor market in accordance with their capabilities and predispositions, as well as on engaging in professional activities. Two talks were delivered to the U.S. Congress, Rising above the Gathering Storm (May 27, 2005) and Research Universities and the Future of America (June 22, 2009). As a result of these reports, Congress and the National Academies recognized innovation as a major driver of the U.S. economic growth and prosperity, and developed two key educational policy recommendations [1].

The first recommendation is to increase research funding, especially in the STEM areas: Science, Technology, Engineering and Mathematics. This recommendation has given rise to a new culture of STEM teaching that includes mentoring, media involvement, and an emphasis on inclusive learning [7].

The second recommendation is the development of closer partnerships between universities and industry [8]. The second recommendation has led universities over the past decade to become research centers, design offices, experimental laboratories, and other key divisions of large industrial corporations. On the one hand, this led to the fact that industrial giants began to invest billions of dollars in the development of universities, thereby saving even more funds on the maintenance of their own laboratories. On the other hand, the personnel problem was solved. Talented young people got access to the latest equipment and large investments from the very first years of study. The university has become attractive not only as a social institution raising the level of education and conferring a certain degree of qualification. The university has become a new social institution providing opportunities for the implementation of individual research and business projects.

The following statistics can be considered as an example. In 2012, the National Science Foundation, an independent agency under the U.S. government responsible for the development of science and technology, received \$ 124 billion from the budget. Within this total funding amount, the U.S. government entered into research contracts with federal governmentcontrolled laboratories and research centers for \$ 46 billion. The industry received $\$ 40$ billion for research, and the U.S. universities $-\$ 32$ billion [9]. Moreover, if federal laboratories and industry were financed for specific research projects, universities were allocated funds for fundamental research in various fields. These studies allowed intermediate results and required less reporting.

The above example proves that already in 2012, the U.S. government began to consider the higher education system as a key part of the state's intellectual potential. If we draw an analogy with the corresponding institutions of Ukraine, then the funding of the Academy of Sciences of Ukraine, research centers at state enterprises, as well as at universities, should be carried out in almost equal proportion. From the point of view of the U.S. government, these are the structures that form the intellectual potential of the state that drives its economic growth.

Pay attention to the research by H. Pylypenko, et al. [10]. The authors presented the results of empirical studies on the relationship between culture and innovation. The study proved that innovative activity directly depends on sociocultural values that determine human dispositions, habits and motivation. It was shown that in the countries with dominant values of "openness to change", inventiveness and innovation are more pronounced when compared to the countries where values of "conservatism" prevail [10].

The research by H. Pylypenko, et al. is fully consistent with the results of the interaction of the U.S. Congress with the
U.S. National Academies. Both recommendations of the U.S. Congress led to a reform of university governance, as well as a change in the basic foundations of teaching management culture in universities. The role of Humanities was rethought and new strategies were developed that significantly influenced the formation of a new management culture among university graduates [11]. The U.S. universities have been transformed into a special enabling environment for institutional innovation. The emphasis was placed on the formation of a new management culture.

The key strategy for the formation of a new management culture in universities was based on the idea of teaching students, researchers and educators the most effective strategies and tactics for launching their own startups from academic platforms. Startups were launched with the support of special courses, government grants, incubators, and private partnerships at the university, regional, state and global levels [12].

The term "university startup" needs clarification. Though, there is no unambiguous definition of it in modern scientific studies, its understanding is conventional [1, 12]. A university startup is a specific college-level startup design course that teaches students how to create commercial companies that have social impact. We emphasize that teaching design for university startups has a clear focus on developing companies with social impact. The main reason for this emphasis is the psychological motivation of students to "change the world". Therefore, students are offered a new management culture in which business is used as a force of public good or as a force that transforms society.

University startups are transforming the dream of the younger generation to "change the world" into particular practices that improve certain aspects of the environment and solve certain social problems.

Taking the university startup design courses, students are taught how to set a problem correctly, be able to develop a solution, find customers, be able to create a simple website and start taking pre-orders, recruit beta testing, and in some cases increase sales. The key goal of the courses is to teach a new management culture that transforms the dream of "changing the world" into particular social practices. Students will learn about the Lean Startup process, which will be useful in future innovation projects and new businesses that change the social system.

On average, university startup design courses have $50+$ hours of tuition and are publicly available. The courses are standardized and use the same methodology and materials that are used in the courses at leading business schools around the world. They are designed and taught by business professors from leading universities. The end result of the courses provides for the opportunity for students to start their own business in two weeks. Moreover, the point is not just to start a "random" business or business as a way of making money. Students are taught how to self-realize internal potentials in business. They are taught to view business as an opportunity to transform society in accordance with their dreams.

The new management culture is based on an important achievement of American universities, which was subsequently implemented in other countries of the world. This is the embodiment of the Bay-Dole Law (1980) in practice. A new management culture, initiated and promoted by the U.S. Congress, has led to a reform of the patent system. The transfer of technology to universities and individuals, who are university employees, has been regulated [13]. According to the resolution of the U.S. Supreme Court, patent protection of universities and its employees was strengthened.

The most important achievement in reforming the state patent system was that universities and university researchers were legally entitled to acquire rights to inventions that were funded by the state through federal research grants [1].

Universities can generate alternative sources of revenue. This is an opportunity to earn on the talents of teachers and 
students, attract public and private investors, and use internal intellectual and tangible resources. Universities are able to attract national grants, as well as funds from private investors, to fund university startups. At the same time, in the case of successful development of the startup, inventions and discoveries are assigned to universities and their employees.

The opportunity to become an owner of innovative discoveries has stimulated universities to develop a new system of incentives and organizational capabilities. The new management culture developed in universities included:

1. Allocating resources to support entrepreneurial initiatives of faculty and students on campus.

2. Implementing career incentives for teachers and students for participating in research projects.

3. Encouraging partnerships with regional business investors, government and global investment companies that are interested in accelerating the implementation of advanced research in regional, government and global production.

Universities began to encourage the creation of startups not only based on university research centers and laboratories, but also on the basis of student initiatives. Universities have developed a close relationship with academic entrepreneurship.

A new university management culture has spurred the development of the management culture among students, researchers and teachers. The university platform began to be used to teach the skills of startup entrepreneurship, or the creation of university startups. University administrators, professors, technology licensing specialists, incubator managers and government grant officers have been interested in creating new startups and integrating startups into the university structure.

A new management culture was formed that aimed to create a thriving entrepreneurial ecosystem for students, researchers and entrepreneurs. The new management culture that emerged in universities had the following advantages [12]:

1. It used hidden network effects.

2. It established links between research and development and industries seeking innovative solutions.

3. It improved the university public image.

4. It motivated the best and talented university representatives to participate in startups that will benefit the university and the public, as well as themselves.

5. It ensured the transformation of the internal potential of talented youth into state capital, which increased the political significance of the state and its security.

Here are some examples. In the prestigious Swiss research magazine Energies, a study was published on the possibilities of reducing greenhouse gas emissions, recycling waste and using renewable energy sources in the Chinese economy during an industrial boom [14]. The peculiarity of this study is that it was funded by a Chinese university, and the study itself was conducted by university startups from five countries. In fact, the territorial attractiveness of universities began to fade into the background, giving way to the university financial capabilities, as well as the degree of development of a new management culture at the university. This example reveals the following benefits of the new management culture:

1. A grant was allocated for a specific study. Communication took place at the level of university faculty.

2 . The task and the sequence of its solving were formulated. Five university startups were created in five universities located in five countries of the world under a grant from a Chinese university during a month. Each startup consisted of a research instructor and several students.

3. Each startup used the scientific and technical potential of the university. It made money for the university and for itself.

4. After completing the work, startups ceased to exist. However, internal satisfaction and experience of international cooperation remained.

The new management culture has proven the dual nature of innovation, which manifests itself in the symbiosis of inno- vation and the product of creativity. On the one hand, the innovative impulse arises from the desire of a person to obtain economic benefits and, on the other hand, from the desire to achieve originality due to national and cultural traditions [10].

The second example is based on the research by A. Binhas [15]. Binhas conducted a case study in Israel, the main goal of which was to test models for integrating immigrant teachers and immigrant students into the new management culture. The importance of this research is reasoned by the fact that the universities of a new breed go beyond the narrow limits of the regional and even national scale. A new management culture is changing the organizational culture. Universities are forced to attract teachers and students from all over the world, focusing exclusively on their ability to create effective and promising university startups, as well as to master regional and state grants.

Binhas proved that the problem of adaptation of teachers and students to the culture of the state where the university is located does not exist [15]. Universities provide the most complete socialization of talented teachers and students, regardless of their national and religious affiliation.

The new management culture is a product of what Heidegger calls the "Errant Man" [16]. A person wanders in search of full-fledged self-actualization, and universities have the opportunity to offer him/her the widest possible range of opportunities for self-actualization.

The Errant Man proves that modern culture cannot be isolated. It is dynamically and constantly evolving. A. Frantsuz researched Central and Eastern Europe as a single political and legal space [17]. The Frantsuz research reveals the features of the transfer of a new management culture to higher education in Ukraine.

Consider the features of the implementation of a new management culture in higher education in Ukraine. It should be noted that the Law of Ukraine "On Higher Education" was adopted in 2014. All subsequent changes to the Law, including the latest version of July 24, 2020, had nothing to do with the introduction of a new management culture [18]. For this reason, higher education in Ukraine does not provide for teaching a new management culture at the legislative level. However, a new management culture, due to the obvious efficiency, exchange of experience, Ukraine's integration into the European space and other factors, still manifests itself in the organization of Ukrainian universities.

Consider the peculiarities of its manifestation, as well as the obstacles standing in the way of a new management culture implementation in higher education in Ukraine.

First, the research by H. Pylypenko, et al. proves that the population of Ukraine is distinguished by a more pronounced orientation towards the values of security, tradition and conservatism, to the detriment of the values of "openness to change". This means that the average Ukrainian is extremely cautious and conservative in their actions. In their psychological portrait there are no dominant needs for novelty, creativity and freedom. They do not have a pronounced predisposition to change and risk [10]. For this reason, individual innovation as a factor in the growth of social welfare is a new challenge for Ukrainian culture. This involves formation of a new Ukrainian management culture that encourages creativity as the basis of a person's innovative search.

In fact, in Ukraine, the question is not about reforming the management culture in higher education, but about reforming the management culture at the state level. The initiative should come from universities, but needs to be promoted at the state level. It means that the state determines the value of the intellectual potential of young people in the overall assessment of their own state capital.

Are Ukrainian universities capable of independently transforming the culture of management? Do they have this potential?

In general, universities have a powerful formative potential. The research by A. Binhas proved the potential of higher 
education to change the current conflict situation. At universities, not only the idea of multiculturalism is being promoted. Using the 'Israeli Hope in Academia' project as an example, Binhas revealed the important role of the Israel academic community in the process of rapprochement between Jews and Arabs [19]. Binhas proves that the potential of universities is much higher than the introduction of new qualities into the national culture. It is able to influence the policy of war and peace, thereby shaping the domestic and foreign policy of the state.

However, higher education in Ukraine, as well as the traditions of Ukrainian universities, differs from the tradition of higher education in Israel. In Israel, higher education was formed by analogy with higher education in the United States. In the United States and Israel, the intellectual potential of young people is seen as a key component of state capital. That is why the issues of higher education are high on the agenda of the legislative and executive authorities of these states.

A paradoxical situation has developed in Ukraine. The Law of Ukraine "On Education" dated 05.09.2017, provides for a new Law of Ukraine "On Higher Education". It creates conditions for radical changes in Ukrainian higher education, including the reforms of university governance and management culture in the universities that are relevant for 2017. However, three years have passed since the adoption of the Law of Ukraine "On Education". The Law of Ukraine "On Higher Education" is still far from final adoption, although it was submitted to the Verkhovna Rada of Ukraine along with the provisions of the Law "On Education". Accordingly, if we assume that in a year or two, the Verkhovna Rada of Ukraine will nevertheless adopt the Law of Ukraine "On Higher Education", then its main provisions will lose their relevance.

For comparison, in the United States, the process of initiating a new management culture, developing the main provisions of the U.S. Higher Education Reform Act, passing the law by Congress and putting it into practice took about 3 years.

Second, the analysis of Ukrainian scientific studies on a new management culture and its significance in higher education in Ukraine and in public administration, in general reveals three key problems:

1. Lack of discourse on the need to reform the legal framework for university management.

2. Explicitly expressed discourse about the prerogative of traditional culture in higher education.

3. The irrelevance of the topic of university startups in Ukrainian higher education.

Take a quick look at these issues.

1. The article "Realization of smart ideas: management and infrastructure aspects" notes the discrepancy between the legislative framework of Ukraine and the idea of developing university startups [20]. However, the author of the article, like other authors researching this issue, does not raise the question of reforming university management. Education in Ukraine, including higher education, is in a state of permanent reform. However, the discourse on this issue does not go beyond the discussion of the quality of reforms. There is no specific formulation of questions about the effectiveness or inefficiency of university management and the quality of the services they provide.

For example, the Law of Ukraine "On Higher Education" does not prohibit the creation of university startups. Therefore, they are created. According to various estimates, their number exceeded 2000 throughout Ukraine [20]. Almost all leading Ukrainian universities have their own startups, business incubators, and others. They encourage their creation within their capabilities. However, the quality of the discourse on this issue looks surprising.

The following comparison can be taken as an example. In the United States, the discourse on a new management culture was initiated at the level of congressmen and university presidents. The current situation at universities was assessed by leading experts in the field. The problems and other negative factors that hinder the development of a new management culture in the U.S. higher education were identified and voiced. Based on the results obtained, the effectiveness of the new management culture was argued and recommendations of the U.S. Congress were developed. The recommendations affected the reform of not only universities, but also other public services that ensure the effectiveness of the implementation of a new management culture in American society.

In Ukraine, this discourse is organized at the level of graduate and doctoral students. This is evidenced by the analysis of publications in scientific journals in Ukraine, as well as the analysis of the literature that the authors of the publications use to argue their ideas.

The discourse lacks the attitude of the Verkhovna Rada of Ukraine, as the highest legislative body of Ukraine, the Academy of Pedagogical Sciences of Ukraine, as well as the Ministry of Education and Science of Ukraine. In addition, as evidenced by the experience of the United States, the implementation of a new management culture requires reforming the State Enterprise "Ukrainian Institute of Intellectual Property", which is subordinate to the Ministry of Economic Development, Trade and Agriculture of Ukraine. Thus, the introduction of a new management culture depends on the coordination and reform of five state institutions of Ukraine, each of which has its own understanding of the management culture and its role in Ukrainian society. None of the aforementioned state institutions is involved in the discourse on the legislative support of a new management culture in Ukraine.

2. Research by H. Pylypenko, et al. proves that the prerogative of traditional culture in Ukrainian higher education is one of the main problems of introducing a new management culture [10]. "Conservative" attitudes established in higher education of Ukraine contradict the foundations of a new management culture. In fact, Ukrainian universities and other academic institutions are not interested in introducing a new management culture, as it provides for personal responsibility at all levels of management.

For example, in 2013, the presidents of 165 leading U.S. universities asked President Obama and members of Congress to bridge the innovation funding gap [1]. The request to the President of the United States and the highest legislative body was motivated by the need for even greater legislative initiatives to facilitate the transformation of the intellectual potential of young people into the state capital of the United States. The main feature of this appeal was that the presidents of the leading U.S. universities not only asked for an increase in government funding for university startups. In return, they took on new commitments to the President and Congress. It was about mutual agreement and benefit. Universities made specific commitments for the end result of the funding received. They guaranteed the state and social significance of the final results of state funding.

Is the governance of Ukrainian universities ready to take responsibility for the funding allocated by the state? Lacking viewpoint of university rectors in the discourse on the implementation of a new management culture leaves this question open.

3. The discussion of university startups in Ukrainian higher education is not relevant. It is enough to compare the number of publications and citations on this topic in the USA, the European Union and Ukraine. There are no articles by Ukrainian authors on this problem in the Web of Science and Scopus databases. In the Google Scholar database, the vast majority of publications on this topic are presented by graduate students and doctoral students. Moreover, the number of publications is incomparably lower than in English.

Third, the perception of a new management culture in Ukraine does not correspond to its understanding in the United States and the European Union. In Ukraine, the creation of university startups is seen as a new source of income for uni- 
versities or as an ordinary entrepreneurial activity [20]. The subject of discourse of Ukrainian researchers is the products produced by university startups, the number of startups and the amount of investment in university startups.

However, we must pay attention to the fact that university startups, just like a new management culture, were created primarily as a socially significant field of activity. These are not just the items produced by university startups that are important for the U.S universities. What is more important is that young people are taught a new management culture, they have the opportunity to realize their dream of "changing the world". Without doubt, it is a priori understood that this change will benefit society. For example, it will lead to the creation of artificial intelligence, new space technologies, etc. [21]. However, the fact that people come to universities not only to gain knowledge is even more important for higher education. Young people began to view universities as a favorable ecosystem for full-fledged individual self-actualization. It is for the sake of developing the "innovative spirit" that a new management culture was created.

Conclusions. In the article, the authors examined a new management culture that was initiated in the United States at the beginning of the $21^{\text {st }}$ century. The new management culture has transformed universities from educational institutions into special ecosystems (known as incubators), in which the intellectual potential of young people was transformed into state capital. Universities have become an important factor in the economic growth of the state and in improving the welfare of society.

The authors considered the features of the implementation of a new management culture in the higher education system of Ukraine. Three key problems were identified and studied, which, according to the authors, make Ukrainian higher education closed for the implementation of a new management culture at this stage of Ukraine's development.

\section{References.}

1. Valdivia, W. (2013). University Start-Ups: Critical for Improving Technology Transfer. Retrieved from https://www.brookings.edu/wp-content/uploads/2016/06/Valdivia_Tech-Transfer v29 No-Embargo.pdf.

2. Bazaluk, O. (2019). Plato's Traditions in Modern Educational Theories. Annals of the University of Craiova - Philosophy Series, 43(1/2019), 5-20.

3. Gerritsen-van Leeuwenkamp, K., Joosten-ten Brinke, D., \& Kesterd, L. (2017). Assessment quality in tertiary education: An integrative literature review. Studies in Educational Evaluation, 55, 94-116. https://doi.org/10.1016/j.stueduc.2017.08.001.

4. Faust, D. G. (2012). By the Book. The New York Times, May 24. Retrieved from https://www.nytimes.com/2012/05/27/ books/review/drew-gilpin-faust-by-the-book.html.

5. Czyż, A., \& Svyrydenko, D. (2019). Science Education as a Response to the Needs of the Modern Open "Education for Everyone" System. Future Human Image, 11, 14-21. https:// doi.org/10.29202/fhi/11/2.

6. Žukauskas, P., Vveinhardt, J., \& Andriukaitienè, R. (2018). The Theoretical Aspect of Management Culture as Part of Organizational Culture. Management Culture and Corporate Social Responsibility, IntechOpen, https://doi.org/10.5772/intechopen.70624.

7. Kricorian, K., Seu, M., Lopez, D., Ureta, E., \& Equils, O. (2020). Factors influencing participation of underrepresented students in STEM fields: matched mentors and mindsets. International Journal of STEM Education 7, 16. https://doi. org/10.1186/s40594-020-00219-2.

8. Novak, O., Levchenko, L., Levchenko, I., \& Kostenko, O. (2019). Features of master's degree programs in Ukraine: formation of administrative competencies. Naukovyi Visnyk Natsionalnoho Hirnychoho Universytetu, (3), 158-163. https://doi. org/10.29202/nvngu/2019-1/18.
9. National Science Foundation's on Science and Engineering Indicators (NSF, 2012). Retrieved from https://www.nsf.gov/ statistics/digest12/globalization.cfm.

10. Pylypenko, H., Lytvynenko, N., \& Barna, T. (2019). Socio-Cultural Context of Innovative Development. Philosophy and Cosmology, 23, 98-111. https://doi.org/10.29202/philcosm $/ 23 / 9$.

11. Rudenko, S., Bazaluk, O., Tsvykh, V., \& Kalmuk, I. (2019). The Role of Philosophical Disciplines in Educational Strategies for Specialist Training in the Field of Public Administration. Naukovyi Visnyk Natsionalnoho Hirnychoho Universytetu, (3), 158-163. https://doi.org/10.29202/nvngu/2019-3/22.

12. Stagars, M. (2015). University Startups and Spin-Offs: Guide for Entrepreneurs in Academia. Apress, Berkeley, CA. https://doi.org/10.1007/978-1-4842-0623-2.

13. Link, A. N., \& Hasselt, M. (2019). On the transfer of technology from universities: The impact of the Bayh-Dole Act of 1980 on the institutionalization of university research. European Economic Review, 119, 472-481. https://doi.org/10.1016/j. euroecorev.2019.08.006.

14. Bazaluk, O., Havrysh, V., Nitsenko, V., Baležentis, T., Streimikiene, D., \& Tarkhanova, E.A. (2020). Assessment of Green Methanol Production Potential and Related Economic and Environmental Benefits: The Case of China. Energies, 13. https://doi.org/10.3390/en1312311.

15. Binhas, A. (2019). Long Term Immigrants as Teachers of New Immigrant Students. Future Human Image, 12, 5-21. https://doi.org/10.29202/fhi/12/1.

16. Dobroskok, I. (2019). Errant Man: The Importance of Cosmological Models in Culture. Philosophy and Cosmology, 23, 90-97. https://doi.org/10.29202/phil-cosm/23/8.

17. Frantsuz, A. (2020). Central and Eastern Europe - the Globalization Process, Hybrid Threats: Political and Legal Aspects. Ukrainian Policymaker, 6, 24-31. https://doi. org/.29202/up/6/3.

18. Verkhovna Rada of Ukraine. Legislation of Ukraine. (n.d.). On Higher Education. Revision on July 24, 2020. Retrieved from https://zakon.rada.gov.ua/laws/show/155618? lang=en\#Text.

19. Binhas, A. (2019). Shared Living in Israel - Higher Education as an Agent of Change in a Conflicted Society. Ukrainian Policymaker, 5, 17-23. https://doi.org/10.29202/up/5/2. 20. Dudkin, P., \& Dudkina, O. (2017). Realization of smart ideas: management and infrastructure aspects. Socio-Economic Problems and the State, 17(2), 56-64.

21. Soroka, L., \& Kurkova, K. (2019). Artificial Intelligence and Space Technologies: Legal, Ethical and Technological Issues. Advanced Space Law, 3, 131-139. https://doi. org/10.29202/asl/2019/3/11.

\section{Культура управління: роль університетських стартапів}

\author{
О. М. Новак ${ }^{1}$, С. М. Мусійчук ${ }^{2}$, Н. О. Зуєнко
}

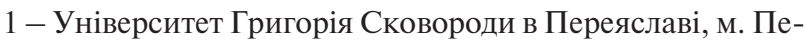
реяслав, Україна, e-mail: novakolyia@gmail.com

2 - Національний університет харчових технологій, м. Київ, Україна

3 - Національний університет біоресурсів і природокористування України, м. Київ, Україна

Мета. Дослідження особливостей імплементації нової культури управління у вищу освіту України.

Методика. Автори використовували методи аналізу й синтезу. Обидва методи забезпечили результати дослідження академічної літератури з обраної проблеми. Методи порівняння та аналогії дозволили зіставити результати дослідження різних держав і регіонів, а також аргументувати висновки. 
Результати. Авторами було виявлено, що формування нової культури управління у вищій освіті було ініційовано в США на початку XXI століття. Дві ключові рекомендації Конгресу з питань освітньої політики відкрили університетам нове джерело доходів. Університети були залучені до економічної стратегії розвитку держави. 3 освітніх установ вони перетворилися в генератор нової культури управління, що перетворювала інтелектуальний потенціал молоді в економічне зростання держави й підвищення добробуту суспільства. У роботі розглянуті особливості імплементації нової культури управління у вищу освіту України. Були виявлені і досліджені три проблеми, що роблять неможливою повноцінну імплементацію нової культури управління в українські університети на даному етапі розвитку держави.

Наукова новизна. Автори викрили нові тенденції у формуванні культури управління у вищій освіті США, а також дослідили особливості їх впливу на реформування вищої освіти в Україні.

Практична значимість. Результати дослідження слід розглядати як рекомендації для втілення нової культури управління у вищу освіту України. Нова культура управління, ініційована Конгресом США, розвиває «інноваційний дух» молоді. Вона перетворює інтелектуальний потенціал молоді в державний капітал. Впровадження нової культури управління у вищу освіту України забезпечить економічне зростання держави і, відповідно, підвищення добробуту українського суспільства.

Ключові слова: культура управління, університетські стартапи, вища освіта США, випускники університетів, вища освіта в Україні, реформи вищої освіти

\section{Культура управления: роль университетских стартапов}

\section{О. М. Новак ${ }^{1}$, С. Н. Мусийчук ${ }^{2}$, Н. А. Зуенко ${ }^{3}$}

1 - Университет Григория Сковороды в Переяславе, г. Переяслав, Украина, e-mail: novakolyia@gmail.com 2 - Национальный университет пищевых технологий, г. Киев, Украина

3 - Национальный университет биоресурсов и природопользования Украины, г. Киев, Украина

Цель. Исследование особенностей имплементации новой культуры управления в высшее образование Украины.
Методика. Авторы использовали методы анализа и синтеза. Оба метода обеспечили результаты исследования академической литературы по выбранной проблеме. Методы сравнения и аналогии позволили авторам сопоставить результаты исследования разных государств и регионов, а также аргументировать выводы.

Результаты. Авторы установили, что формирование новой культуры управления в высшем образовании было инициировано в США в начале 21 столетия. Две ключевые рекомендации Конгресса по вопросам образовательной политики открыли университетам новый источник доходов. Университеты оказались вовлечены в экономическую стратегию развития государства. Из образовательных учреждений они превратились в генератор новой культуры управления, которая преобразовывала интеллектуальный потенциал молодежи в экономический рост государства и повышение благосостояния общества. В работе рассмотрены особенности имплементации новой культуры управления в высшее образование Украины. Были выявлены и исследованы три проблемы, делающие невозможной полноценную имплементацию новой культуры управления в украинские университеты на данном этапе развития государства.

Научная новизна. Авторы раскрыли новые тенденции в формировании культуры управления в высшем образовании США, а также исследовали особенности их влияния на реформирование высшего образования в Украине.

Практическая значимость. Результаты исследования следует рассматривать как рекомендации для воплощения новой культуры управления в высшее образование Украины. Новая культура управления, инициированная Конгрессом США, развивает «инновационный дух» молодежи. Она превращает интеллектуальный потенциал молодежи в государственный капитал. Внедрение новой культуры управления в высшее образование Украины обеспечит экономический рост государства и, соответственно, повышение благосостояния украинского общества.

Ключевые слова: культура управления, университетские стартапы, высшее образование в США, выпускники университетов, высшее образование в Украине, реформы высшего образования

Recommended for publication by M. V. Bratko, Doctor of Science in Pedagogy. The manuscript was submitted 22.02.20. 